\title{
Relationship between the change of soil moisture content of different soil layers and maize yield
}

Lajos Fülöp Dóka

University of Debrecen Faculty of Agricultural and Food Sciences and Environmental Management

Institute for Plant Sciences, Debrecen

doka@agr.unideb.hu

\section{SUMMARY}

The development of chernozem soil water management and its relationship with maize yields was studied in a 30-years long-term field experiment with different crop-rotation systems (mono-, bi- and triculture), in three crop years with different natural precipitation: a drought (2007), a wet (2008) and a dry (2009 one. The relevant soil layer was divided to three sub-layers: (0-60 cm, 61-120 cm, 121-200 cm) in which the development of soil moisture content was investigated during the whole vegetation. From the results it can be stated that change of the water stock of the upper soil layer $(0-60 \mathrm{~cm})$ was the most intensive. Both the direct effect of natural precipitation and irrigation could be observed in the most obvious way in it. Yield result of maize and the highest water supply deficit values in the vegetation were compared in our work too. According to the results it was revealed that among the three studied crop rotation systems it was the monoculture, the success of production of which depends the most of water supply. The most favourable crop rotation system was the triculture from both the aspect of the yield of produced crops and the favourable soil properties too.

Keywords: soil layer, water management, crop rotation, maize, yield

\section{ÖSSZEFOGLALÁS}

30 éves tartamkísérletben vizsgáltuk a csernozjom talaj vizháztartásának alakulása és a kukorica terméseredménye közötti kapcsolatot, különbözö vetésváltási rendszerekben (mono-, bi- és trikultúra), három eltérö csapadékellátottságú évjáratban: egy aszályos (2007), egy csapadékos (2008) és egy száraz (2009). A mértékadó talajréteget három szintre osztottuk, (0-60 cm, 61-120 cm, 121-200 cm) melyekben vizsgáltuk a talajnedvesség tenyészidöbeli alakulását. Az eredmények alapján a felsö $(0-60 \mathrm{~cm})$ talajszint nedvességkészlet változása volt a legintenzivebb, mind a csapadék, mind az öntözés közvetlen hatása itt mutatható ki a legegyértelmübben. Összehasonlitottuk a kukorica terméseredményét és a tenyészidőszak legnagyobb vizellátottsági hiányértékeit. Az eredményekböl megállapitható, hogy a vizsgált három vetésváltási rendszer közül a monokultúrás termesztés eredményessége függ a legnagyobb mértékben a vizellátottsági viszonyoktól, valamint a trikultúrás rendszer a legkedvezöbb, mind a vetésváltásban szereplö növények termését, mind a kedvezö talajállapotokat tekintve.

Kulcsszavak: talajszelvény, vizháztartás, vetésváltás, kukorica, termés

\section{INTRODUCTION}

In the most significant maize production areas of Hungary the efficiency and safety of production depents in particular from water supply. Under the Hungarian climatic conditions precipitation and temperature are the two factors that basically affect not only the growth of maize, but the average yield results too (Surányi, 1957; Dégen, 1967; Antal and Jolánkai, 2005; Kismányoky, 2005). Essential nutrients are taken up by plant in dissolved form and water plays a basic role in photosynthesis. Therefore plants need water during the whole vegetation period, but the amount of the demanded water varies from sowing till harvest. The main source of this essential water amount in Hungary is atmospheric precipitation, that is stored in the soil and from there it will be transported to plants. Since plants take up water through their root system, the most determining for this is the available water amount in the soil. The given crop year affects yield production and irrigation has yield increasing effect (Blaskó and Zsigrai, 2000; Kismányoky and Debreczeniné, 2002; Bharati et al., 2007; Kumar, 2008). Deviations in yield amounts are mainly determined by the amount of precipitation in May and soil water in June. Water affects the utilization of nutrients. The periodic filling of soil (via precipitation or irrigation) ensures continuous supply for plants and the develop- ment and sustenance of optimal environment circumstances (Huzsvai and Nagy, 2005; Nagy and Kovács, 2005; Nagy, 2007).

All human plant production activities' aim is basically the production of higher yields with even better quality. For this purpose plant populations need - among several factors - adequate water supply that is supplied naturally or as a result of human activities, irrigation to plant roots (Kruzsilin, 1964; Antal and Jolánkai, 2005; Izsáki, 2006).

\section{MATERIAL AND METHODS}

Investigations were carried out in the polifactorial long-term field experiment in the crop years of 2007 , 2008 and 2009 at the Látókép Experimental Station of the University of Debrecen, Institute for Plant Sciences, that was set up by Professor László Ruzsányi† in 1983 and conducted by Professor Péter Pepó since 2004. The experimental soil is a chernozem soil with good water infiltration and storage capacity. The area of each experimental plot is $41.1 \mathrm{~m}^{2}$.

In the experiment we have used a nutrient supply level of $\mathrm{N}_{120} \mathrm{P}_{90} \mathrm{~K}_{90}$, two water supply levels (treatment $\ddot{\mathrm{O}}_{1}=$ without irrigation, treatment $\ddot{\mathrm{O}}_{2}=$ irrigated), plant density of 60000 plants ha ${ }^{-1}$ and three different crop rotation systems (mono-, bi- and triculture). Soil 
cultivation, plant protection and harvest measurements were the same in case of all treatments. The investigated maize hybrid was Reseda (PR37M81).

In the irrigated treatments $\left(\ddot{O}_{2}\right)$ following water amounts were applied in the given times:

Year 2007: 04. May - $50 \mathrm{~mm}$ water

$$
\begin{aligned}
& \text { 23. May }-50 \mathrm{~mm} \text { water } \\
& \text { 04. June }-50 \mathrm{~mm} \text { water } \\
& \text { 30. June }-50 \mathrm{~mm} \text { water }
\end{aligned}
$$

Year 2008 was favourable from the aspect of maize water supply; therefore there was non need to apply any additional irrigation water in any treatment.

Year 2009: 04. May - $50 \mathrm{~mm}$ water

$$
\text { 23. May }-50 \mathrm{~mm} \text { water }
$$

In order to study the soil water management soil samples were taken 6 times during the vegetation of in all three crop years from each $20 \mathrm{~cm}$ sub-layer of the upper $200 \mathrm{~cm}$ layer from the treatments mono-, bi- and triculture, the plant density of 60000 plants per hectare and the irrigation variants $\ddot{O}_{1}$ and $\ddot{O}_{2}$. The first sampling time was before sowing, the following four during the main phonological phases (3-4 leaves, grain filling, ripening), while the sixth one after harvest.

Soil water content was determined in a drying oven and converted to and expressed as $\mathrm{V} / \mathrm{V} \%$ using soil density value (Buzás, 1993).

Analysing the precipitation and temperature data of the studied three crop years it can be stated that the water supply was rather unbalanced in 2007 (Table 1). In the first part of the vegetation - April, May, June and July - the amount of fallen precipitation was low. At the end of the grain filling and the beginning of the ripening phase of maize water supply became more favourable: $77 \mathrm{~mm}$ precipitation fell during August.
From April until the end of September, from the sowing until the harvest of maize fell altogether $283.8 \mathrm{~mm}$ precipitation that was $61.3 \mathrm{~mm}$ lower than the 30 years average value of the relevant period. In contrast, temperature average value was $2{ }^{\circ} \mathrm{C}$ higher than the 30 years average.

The whole crop year of 2008 was wetter than the previous one. The distribution of precipitation was really favourable from the aspect of maize water supply. Already at the beginning of the vegetation period, in the early phase of sowing the amount of soil water was enough. This favourable state was sustained by the rainfalls from June until the end of July. The good water supply is confirmed by the total amount of fallen precipitation during the whole vegetation: in contrast to the 30 -years average value of the respective period $(345.1 \mathrm{~mm})$ the amount of fallen precipitation was $138.8 \mathrm{~mm}$ higher.

The average temperature value was lower than in the previous year (2007). Regarding these data it can be stated that the weather conditions of the vegetation 2008 was extreme favourable from the aspect of maize production.

The crop year of 2009 was rather dry - similar to that of 2007. The amount of natural precipitation was inadequate already in the phase of sowing, shooting and early development. This tendency remained the same during the summer months, except for June, when the highest amount of precipitation fell $(96.6 \mathrm{~mm})$ that "saved" maize plants. The total amount of fallen precipitation $(168.8 \mathrm{~mm})$ was even lower than that of the drought crop year of 2007. Parallel to the lack of precipitation high temperature values were measured that made the consequences of water deficit more severe.

Monthly amounts of fallen precipitation during maize vegetation and their deviations from the 30-years average values (Debrecen, 2007-2009)

\begin{tabular}{lrrrrrrr}
\hline & \multicolumn{2}{c}{2007} & \multicolumn{2}{c}{2008} & \multicolumn{3}{c}{2009} \\
\cline { 2 - 8 } & $\begin{array}{c}\text { Measured value } \\
(\mathrm{mm})\end{array}$ & $\begin{array}{c}\text { Deviation } \\
(\mathrm{mm})\end{array}$ & $\begin{array}{c}\text { Measured value } \\
(\mathrm{mm})\end{array}$ & $\begin{array}{c}\text { Deviation } \\
(\mathrm{mm})\end{array}$ & $\begin{array}{c}\text { Measured value } \\
(\mathrm{mm})\end{array}$ & $\begin{array}{c}\text { Deviation } \\
(\mathrm{mm})\end{array}$ & $\begin{array}{c}30 \text {-years average } \\
\text { value }(\mathrm{mm})\end{array}$ \\
\hline April & 3.6 & -38.8 & 74.9 & 32.5 & 9.9 & -32.5 & 42.4 \\
May & 54.0 & -4.8 & 47.6 & -11.2 & 20.1 & -38.7 & 58.8 \\
June & 22.8 & -56.7 & 140.1 & 60.6 & 96.6 & 17.1 & 79.5 \\
July & 39.7 & -26.0 & 144.9 & 79.2 & 9.2 & -56.5 & 65.7 \\
August & 77.6 & 16.9 & 34.2 & -26.5 & 11.3 & -49.4 & 60.7 \\
September & 86.1 & 48.1 & 42.2 & 4.2 & 21.7 & -16.3 & 38.0 \\
Total precipitation $(\mathrm{mm})$ & 283.8 & -61.3 & 483.9 & 138.8 & 168.8 & -176.3 & 345.1 \\
Temperature average $\left({ }^{\circ} \mathrm{C}\right)$ & 18.8 & 2.0 & 17.4 & 0.6 & 19.5 & 2.7 & 16.8 \\
\hline
\end{tabular}

\section{RESULTS}

The development of soil water stock of the upper $200 \mathrm{~cm}$ soil layer was compared in the not irrigated $\left(\ddot{O}_{1}\right)$ and irrigated $\left(\ddot{O}_{2}\right)$ treatments each crop rotation system in the crop year of 2007, 2008 and 2009. The relevant soil layer was divided to 3 sub-layers according to the rooting depths of maize: $0-60 \mathrm{~cm}-$ most of maize roots develop in this layer; $61-120 \mathrm{~cm}$ - some roots, approximately one third of the maize root system reach down to this layer during plant growth; $121-200 \mathrm{~cm}-$ a less determining soil layer from the aspect of maize root growth, however some roots of the plants reach this layer and it is relevant from the aspect of water management of the whole soil profile. The water content results of the $20 \mathrm{~cm}$ sub-layers are calculated as average values in the description of the results of each $60 \mathrm{~cm}$ sub-layer.

Regarding the results of the crop year 2007 (Table 2) it can be stated that soil water stock decreased significantly until August in all three crop rotation systems (in April - the beginning of the vegetation soil water content varied between 17 and $26 \mathrm{~V} / \mathrm{V} \%$, while in August only values between 12 and $18 \mathrm{~V} / \mathrm{V} \%$ were measured). 
Table 2.

Soil moisture content (V/V\%) in mono-, bi- and triculture crop rotation system in the crop years of 2007-2008-2009 (60 000 plants ha $\left.{ }^{-1}, \mathrm{~N}_{120}+\mathrm{PK}\right)$

\begin{tabular}{|c|c|c|c|c|c|c|c|}
\hline \multirow{3}{*}{ Sampling time } & \multirow{3}{*}{$\begin{array}{l}\text { Crop rotation } \\
\text { system }\end{array}$} & \multicolumn{3}{|c|}{ Not irrigated } & \multicolumn{3}{|c|}{ Irrigated } \\
\hline & & \multicolumn{3}{|c|}{ Soil layer $(\mathrm{cm})$} & \multicolumn{3}{|c|}{ Soil layer $(\mathrm{cm})$} \\
\hline & & $0-60$ & $61-120$ & $121-200$ & $0-60$ & $61-120$ & $121-200$ \\
\hline \multirow[t]{3}{*}{03.20 .2007} & monoculture & 23.28 & 15.10 & 17.67 & 24.70 & 16.01 & 19.78 \\
\hline & biculture & 26.08 & 21.68 & 20.42 & 29.15 & 24.82 & 22.73 \\
\hline & triculture & 26.04 & 19.93 & 20.76 & 25.72 & 21.11 & 19.17 \\
\hline \multirow[t]{3}{*}{04.27 .2007} & monoculture & 23.44 & 16.91 & 19.30 & 25.92 & 19.38 & 20.71 \\
\hline & biculture & 25.89 & 22.11 & 21.50 & 27.58 & 25.10 & 23.17 \\
\hline & triculture & 24.42 & 18.29 & 20.71 & 24.84 & 20.60 & 20.30 \\
\hline \multirow[t]{3}{*}{ 06.04.2007 } & monoculture & 23.33 & 17.87 & 19.76 & 27.67 & 21.60 & 20.71 \\
\hline & biculture & 24.68 & 22.30 & 21.32 & 28.89 & 25.88 & 23.79 \\
\hline & triculture & 24.78 & 20.11 & 20.88 & 26.07 & 23.57 & 21.84 \\
\hline \multirow[t]{3}{*}{ 07.04.2007 } & monoculture & 14.30 & 13.87 & 18.20 & 22.38 & 18.49 & 18.69 \\
\hline & biculture & 16.62 & 12.50 & 15.78 & 20.46 & 18.98 & 22.09 \\
\hline & triculture & 15.72 & 13.63 & 19.05 & 19.95 & 16.15 & 19.43 \\
\hline \multirow[t]{3}{*}{ 08.16.2007 } & monoculture & 13.60 & 11.67 & 12.01 & 16.07 & 11.85 & 11.41 \\
\hline & biculture & 14.47 & 11.37 & 11.74 & 11.19 & 10.03 & 15.28 \\
\hline & triculture & 16.38 & 13.06 & 11.68 & 14.24 & 12.90 & 13.65 \\
\hline \multirow[t]{3}{*}{ 10.05.2007 } & monoculture & 23.88 & 18.75 & 14.24 & 28.57 & 21.39 & 15.45 \\
\hline & biculture & 27.66 & 16.79 & 13.52 & 29.73 & 20.17 & 20.06 \\
\hline & triculture & 27.84 & 18.88 & 17.06 & 29.36 & 17.48 & 14.19 \\
\hline \multirow[t]{3}{*}{ 03.04.2008 } & monoculture & 28.57 & 24.42 & 22.75 & 30.21 & 25.07 & 21.48 \\
\hline & biculture & 27.45 & 24.75 & 22.99 & 28.48 & 25.90 & 23.90 \\
\hline & triculture & 30.58 & 22.10 & 18.09 & 29.01 & 23.67 & 20.42 \\
\hline \multirow[t]{3}{*}{ 09.05.2008 } & monoculture & 28.25 & 24.51 & 23.63 & 28.58 & 24.46 & 22.55 \\
\hline & biculture & 26.74 & 24.41 & 22.12 & 28.37 & 24.96 & 23.42 \\
\hline & triculture & 29.29 & 23.56 & 20.48 & 27.45 & 23.56 & 22.48 \\
\hline \multirow[t]{3}{*}{ 25.06.2008 } & monoculture & 26.50 & 24.19 & 24.27 & 25.91 & 24.00 & 24.27 \\
\hline & biculture & 24.85 & 24.35 & 23.55 & 27.50 & 25.28 & 23.69 \\
\hline & triculture & 25.99 & 23.96 & 22.00 & 25.86 & 23.82 & 23.74 \\
\hline \multirow[t]{3}{*}{ 18.07.2008 } & monoculture & 22.60 & 17.69 & 20.84 & 24.67 & 19.74 & 21.81 \\
\hline & biculture & 24.86 & 19.94 & 21.19 & 24.83 & 19.22 & 22.43 \\
\hline & triculture & 21.96 & 17.94 & 20.01 & 24.17 & 19.88 & 21.03 \\
\hline \multirow[t]{3}{*}{ 10.09.2008 } & monoculture & 21.50 & 18.95 & 19.86 & 21.34 & 18.30 & 18.75 \\
\hline & biculture & 21.09 & 17.92 & 19.96 & 21.45 & 18.56 & 20.14 \\
\hline & triculture & 19.61 & 15.01 & 18.31 & 20.89 & 18.11 & 19.70 \\
\hline 02.10 .2008 & monoculture & 23.78 & 18.25 & 19.02 & 22.05 & 16.50 & 18.82 \\
\hline & biculture & 20.64 & 16.25 & 19.43 & 22.07 & 17.04 & 19.95 \\
\hline & triculture & 19.17 & 13.77 & 18.15 & 22.15 & 17.91 & 20.15 \\
\hline 03.04.2009 & monoculture & 28.59 & 23.61 & 24.17 & 27.39 & 25.09 & 23.31 \\
\hline & biculture & 28.07 & 24.62 & 24.22 & 31.03 & 25.41 & 24.95 \\
\hline & triculture & 27.78 & 24.57 & 22.91 & 28.62 & 25.16 & 23.01 \\
\hline 24.04.2009 & monoculture & 26.94 & 24.23 & 23.68 & 26.50 & 23.49 & 24.37 \\
\hline & biculture & 27.14 & 23.67 & 24.11 & 29.23 & 25.77 & 25.41 \\
\hline & triculture & 26.70 & 23.39 & 22.96 & 26.27 & 22.52 & 21.97 \\
\hline 26.05.2009 & monoculture & 23.12 & 21.96 & 22.21 & 26.06 & 24.28 & 23.00 \\
\hline & biculture & 26.01 & 23.29 & 23.11 & 29.53 & 26.12 & 25.05 \\
\hline & triculture & 22.78 & 22.83 & 22.24 & 26.29 & 23.92 & 22.17 \\
\hline 01.07.2009 & monoculture & 24.18 & 19.50 & 22.89 & 22.70 & 19.54 & 21.93 \\
\hline & biculture & 23.86 & 21.09 & 21.70 & 27.64 & 24.49 & 24.46 \\
\hline & triculture & 21.60 & 19.94 & 21.68 & 24.54 & 20.06 & 21.78 \\
\hline 31.08.2009 & monoculture & 16.14 & 13.35 & 12.87 & 15.38 & 12.76 & 11.73 \\
\hline & biculture & 15.82 & 13.21 & 13.91 & 18.06 & 16.20 & 19.52 \\
\hline & triculture & 14.40 & 11.98 & 13.61 & 15.36 & 13.08 & 11.73 \\
\hline 29.09.2009 & monoculture & 15.67 & 13.08 & 13.95 & 18.66 & 13.78 & 12.94 \\
\hline & biculture & 16.63 & 12.63 & 12.43 & 18.73 & 14.98 & 16.95 \\
\hline & triculture & 16.58 & 12.64 & 13.74 & 17.10 & 13.22 & 14.51 \\
\hline
\end{tabular}


It's worth analysing the development of water management of all three studied soil layers. Let's have a closer look at the water management of not irrigated treatments. The water loss of the upper $0-60 \mathrm{~cm}$ soil layer was - with some deviations - slight but continuous. This small extent, but continuous decreasing tendency was accelerated in July and soil water content reached the minimal values in August (12-16 V/V\%). In case of the last sampling time the moderate increment of the measured values can be attributed to the rain falls of the early autumn season, just as to the fact that the intensity of physiological processes and the assimilation and transpiration leaf area of maize stands decreased significantly since August.

In the layer $61-120 \mathrm{~cm}$ similar processes could be observed than in the upper layer. In the middle of the vegetation period (July) in the flowering vegetation phase the root biomass reached this soil layer. This is confirmed by the soil water content data $(12-16$ $\mathrm{V} / \mathrm{V} \%$ ). In the end of the vegetation similar increment of moisture content (24-28 V/V\%) was observed, but its extent was significantly below the upper layers.

In the deepest studied soil layer $(121-200 \mathrm{~cm}) \mathrm{a}$ decreasing tendency - with smaller deviations - could be observed. This can be explained by the fact that the significant water loss in the upper soil layers in the period of July-August was supplied from this level via water transfer as water vapour and steam. The fact that the middle soil layer $(61-120 \mathrm{~cm})$ became slightly more wet $(14-17 \mathrm{~V} / \mathrm{V} \%)$ again in the end of the vegetation period can be explained by this in part. In case of the irrigated treatments the development of the upper $0-60 \mathrm{~cm}$ soil layer was similar to the not irrigated plots. In contrast, the measured values were higher all through the vegetation period (by $4-5 \mathrm{~V} / \mathrm{V} \%$ on average). Regarding the depth of the soil layer the soil water content increasing effect of irrigation water and natural precipitation could be observed in the most intensive way in the upper soil layer, but this positive effect could be revealed in the middle soil layer too: the minimum values of August were $2-3 \mathrm{~V} / \mathrm{V} \%$ higher in the irrigated than in the not irrigated treatments. The soil water stock increasing effect of irrigation could not be observed in the lowest sol layer in case of mono- and triculture.

In the crop year of 2008 soil water content was favourable for the maize crop in all three crop rotation systems and in both the not irrigated $\left(\ddot{O}_{1}\right)$ and the irrigated $\left(\ddot{\mathrm{O}}_{2}\right)$ treatments: values between 18 and 30 $\mathrm{V} / \mathrm{V} \%$ were measured. Soil water content was already favourable before the sowing and the beginning of maize vegetation (22-31 V/V\%). This ensured optimal water supply conditions for shooting and early plant development. The fact that the given crop year was optimal for maize growth and its water demand was supplied in all phonological phases of the vegetation is confirmed by the calculated results. Soil moisture content values were all over the whole vegetation higher than in the previous drought crop year of 2007 (in 2007 main moisture content values between 11 and $18 \mathrm{~V} / \mathrm{V} \%$ were measured, while in 2008 these varied between 18 and $27 \mathrm{~V} / \mathrm{V} \%$ ). At the end of the vegetation period the soil moisture content of the main root zone $(0-60 \mathrm{~cm})$ was close to the limit of the unavailable water amount (16-23 V/V\%). However, this state did not affect plant development, grain production, grain filling of the maize stand, i.e. the amount of harvested yield directly. Regarding its dynamics, the water loss processes of the $0-60 \mathrm{~cm}$ soil layer show a slightly decreasing tendency. The sudden decrement of soil moisture by $3-4 \mathrm{~V} / \mathrm{V} \%$ in the grain filling vegetation phase was due to the high water demand of the large vegetative and generative plant biomass.

The same tendency could be observed on the soil layer $61-120 \mathrm{~cm}$, but in the last sampling time there could no increment be observed and the moisture content did not differ from the values of the period end of August - beginning of September (16-21 V/V\%). The reason for this is the fact that - beside the natural precipitation - this layer had a contributing role in the filling of the upper soil layer via different water transfer processes in the soil. The layer $121-200 \mathrm{~cm}$ shows similar tendency to the upper ones, except for the end of the vegetation, where moisture from this layer was supplied to the upper, relatively drier layers: parallel to the increment of the moisture content of the upper $61-120 \mathrm{~cm}$ layer the moisture content values of the layer below stagnated. Due to the fact that because of the favourable distribution of the natural precipitation during the vegetation there was no need to apply any additional irrigation water in the crop year of 2008 no significant difference between the moisture content of not irrigated and irrigated plots could be observed.

In the crop year of 2009 soil moisture content vales in the beginning of the vegetation, i.e. before sowing were similar to those in the crop years 2007 and 2008 (24-30 V/V\%) in all three crop rotation systems and in case of all water supply treatments.

The moisture stock of the soil layer $0-60 \mathrm{~cm}$ showed - with smaller deviances - decreasing tendency in the first half of the vegetation. Due to the more than $100 \mathrm{~mm}$ precipitation that fell in June there was enough available moisture for the plants in the phase of flowering. Until August the moisture contents decreased by 8 $9 \mathrm{~V} / \mathrm{V} \%$, which means the lowest values during the whole vegetation as the moisture content increased again by $2-3 \mathrm{~V} / \mathrm{V} \%$ by the upwards transfer from the lower layers till the end of the vegetation.

Regarding the development of soil moisture content during the vegetation the $61-120 \mathrm{~cm}$ soil layer showed similar dynamics as the layer above it. However, in the phase of harvest moisture content values did not increase, but showed stagnating tendency $(13-15 \mathrm{~V} / \mathrm{V} \%)$ in this layer, because moisture was supplied to the upper layer from this one and due to the drought the supplement via upwards moisture transfer from the lower layer was not ensured. The same tendency was found in case of the soil layer 121-200 cm during the vegetation too. The middle soil layer $(61-120 \mathrm{~cm})$ showed a decreasing trend between April and the beginning of July. From the beginning of July until the middle-end of August maize roots reached this soil layer and because of this the moisture content of this layer decreased drastically. The extent of this decrement depended on the water supply of the given crop year: while in 2007 and 2009 this extent was $8-10 \mathrm{~V} / \mathrm{V} \%$, in 2008 only $3-4 \mathrm{~V} / \mathrm{V} \%$. 
Considering the effect of irrigation in the two crop years where any was applied it can be stated that in the crop years of 2007 and 2009 irrigation affects mainly the root zone of the upper 0-60 cm soil layer: it filled the upper layer approximately to field capacity and thus it resulted favourable water and nutrient supply circumstances for the plants. As irrigation was not applied anymore and plants disposed only of the natural atmospheric precipitation, the soil moisture content started to decrease.

The $61-120 \mathrm{~cm}$ soil layer's moisture content of the irrigated plots was very similar to the not irrigated ones. This confirms that irrigation affects mainly in the upper soil layer, where it increases the water stock. In a drought crop year (2007) irrigation water partly turned up even below the $0-60 \mathrm{~cm}$ soil layer: more in the $61-120 \mathrm{~cm}$ layer and in a very small extent in the lowest investigated layer (1-3 V/V\%).

In 2008 favourable after effect of irrigation could be revealed: the measured values show higher soil moisture content not only in the upper layer, but in the second root zone one layer below.

The development of water management of the plant production space has a significant effect on yield results as well. Water management processes are influenced and determined by both agroecological and agrotechnical factors. The given crop year has a great effect on soil water management, its moisture content and through this the crop yield too. Table 3 calls the attention to the monitoring of moisture properties of plant stands and to the improvement of soil water management. This table compares the highest calculated water deficit values during maize vegetation period (August) and yield data in the studied three crop years.

The deficit precipitation in the crop years 2007 and 2009 affected soil water management as well. In the grain filling phase of maize in case of the not irrigated treatments following water deficit values were calculated: in monoculture $356 \mathrm{~mm}$, in biculture $355 \mathrm{~mm}$ and in the triculture crop rotation system $332 \mathrm{~mm}$. These deficit values affected yield amount that were $4228 \mathrm{~kg}$ $\mathrm{ha}^{-1}$ in monoculture $7696 \mathrm{~kg} \mathrm{ha}^{-1}$ in biculture and $6890 \mathrm{~kg} \mathrm{ha}^{-1}$ in triculture respectively in the crop year of 2007. Regarding the maximal water deficit values of the vegetation period, no significant effect of the irrigation could be revealed between the not irrigated and irrigated treatments. This can be explained by the following: plants showed the highest water demand in this generative phase of the vegetation in both water supply treatments, so they utilized the total amount of the previously applied irrigation water for their growth and yield production processes. Yield results confirm this, where irrigated treatments show significantly higher yield amounts in all treatment combination. In contrast to the drought crop year of 2007 the optimal water supply in the vegetation of 2008 yield increments of $9581 \mathrm{~kg} \mathrm{ha}^{-1}$ (monoculture), $6360 \mathrm{~kg} \mathrm{ha}^{-1}$ (biculture) and $6732 \mathrm{~kg} \mathrm{ha}^{-1}$ (triculture) were measured in the respective not irrigated treatments.

Despite the fact that the crop year of 2009 was dry too, different results have been revealed. Soil moisture content values confirm high water deficit in this crop year too. In the treatments without any applied irrigation water, following water deficit values were calculated for the period of end of August - beginning of September: $324 \mathrm{~mm}$ in monoculture, $318 \mathrm{~mm}$ in biculture and $336 \mathrm{~mm}$ in triculture. However the difference in the yield results was not that significant: in monoculture we measured $5035 \mathrm{~kg} \mathrm{ha}^{-1}$, in biculture $1727 \mathrm{~kg} \mathrm{ha}^{-1}$, while in triculture $3462 \mathrm{~kg} \mathrm{ha}^{-1}$ lower yields than in the previous crop year of 2008. This can be explained by the fact that in June 2009 fell an even higher amount of precipitation than the 30-years average $(96.6 \mathrm{~mm}$, while the 30 -years average is $79.5 \mathrm{~mm}$ ) that had a very favourable effect on grain yield production processes.

Analysing the effect of crop rotation as agrotechnical factor it can be stated that there was no difference in the maximal water deficit values, regardless the pre-crop maize plants used up the soil moisture until August in all three crop rotation systems. In contrast significant different have been measured in yield results of the dry crop years (2007 and 2009): compared to the monoculture system significant yield increments were measured in the bi- and triculture systems. Compared to the monoculture system yield increments of $3468 \mathrm{~kg} \mathrm{ha}^{-1}$ in biculture and $2662 \mathrm{~kg} \mathrm{ha}^{-1}$ in triculture were measured in the not irrigated, while in case of the irrigated treatments this increment was $2461 \mathrm{~kg} \mathrm{ha}^{-1}$ in biculture and $2798 \mathrm{~kg} \mathrm{ha}^{-1}$ in triculture in the crop year 2007. In 2009 the not irrigated biculture treatments showed a yield increment of $3555 \mathrm{~kg} \mathrm{ha}^{-1}$ and triculture $1386 \mathrm{~kg} \mathrm{ha}^{-1}$, while irrigated biculture treatments $2995 \mathrm{~kg} \mathrm{ha}^{-1}$ and triculture $1885 \mathrm{~kg} \mathrm{ha}^{-1}$ in contrast to the results of the monoculture treatments. All these results confirm that the long term monoculture production system is not the right production system for maize. This contrast between the three studied crop rotation systems was not really expressed in the rather wet crop year of 2008. So because of the even drier weather conditions and the even more frequent drought crop years in Hungary it is recommended to avoid monoculture cropping in maize production.

This is confirmed by the yield results of the irrigated treatments too. In the very dry and drought crop year of 2007 irrigation resulted significant yield increment. Due to the applied irrigation water a grain yield increment of $4005 \mathrm{~kg} \mathrm{ha}^{-1}$ was measured in monoculture, while in biculture its extent was $2998 \mathrm{~kg} \mathrm{ha}^{-1}$ and in triculture $4141 \mathrm{~kg} \mathrm{ha}^{-1}$. This proves that the efficiency of monoculture crop production depends significantly from water supply circumstances. In the crop year of 2009 the yield increment due to the irrigation could be significantly observed however, in smaller extent: in monoculture we measured $2199 \mathrm{~kg} \mathrm{ha}^{-1}$, in biculture $1639 \mathrm{~kg} \mathrm{ha}^{-1}$ and in triculture $2698 \mathrm{~kg} \mathrm{ha}^{-1}$ (Table 3).

There was no difference in the water deficit values of the not irrigated and irrigated treatments in the two dry crop years (2007 and 2009). This can be explained by the fact that maize plants utilized the applied irrigation water amount effectively in the vegetative and rather in the generative growth phase. This is confirmed by the significantly higher yield amounts of the irrigated treatments in contrast to the not irrigated ones. Comparing maize yield results and the highest water deficit values of the vegetation period it can be stated that the highest soil water deficit values were calculated in case of the crop year 2007 and yield amounts were the lowest in 
this year as well. Due to the fact that the crop year of 2008 was rather wet, soil water deficit values were the lowest and yield amounts were the highest in this year. From the aspect of both the deficit values of water supply and yield results the crop year of 2009 can be ranked between the other two studied years. In case of both dry crop years (2007 and 2009) the yield increment of the irrigated treatments was significant.

Table 3.

The effect of water management $o$ the chernozem soil and crop rotation on the yield of maize in different crop years (60 000 plants ha ${ }^{-1}, N_{120}+$ PK) (Debrecen, 2007-2009)

\begin{tabular}{|c|c|c|c|c|c|c|}
\hline & \multicolumn{2}{|c|}{ Monoculture } & \multicolumn{2}{|c|}{ Biculture } & \multicolumn{2}{|c|}{ Triculture } \\
\hline & $\begin{array}{l}\text { Max. water deficit } \\
(\mathrm{mm})\end{array}$ & $\begin{array}{c}\text { Yield } \\
\left(\mathrm{kg} \mathrm{ha}^{-1}\right)\end{array}$ & $\begin{array}{l}\text { Max. water deficit } \\
(\mathrm{mm})\end{array}$ & $\begin{array}{c}\text { Yield } \\
\left(\mathrm{kg} \mathrm{ha}^{-1}\right)\end{array}$ & $\begin{array}{l}\text { Max. water deficit } \\
(\mathrm{mm})\end{array}$ & $\begin{array}{c}\text { Yield } \\
\left(\mathrm{kg} \mathrm{ha}^{-1}\right)\end{array}$ \\
\hline \multicolumn{7}{|c|}{2007} \\
\hline Not irrigated & 356 & 4228 & 355 & 7696 & 332 & 6890 \\
\hline Irrigated & 345 & 8233 & 354 & 10694 & 334 & 11031 \\
\hline Yield increment & - & 4005 & - & 2998 & - & 4141 \\
\hline $\mathrm{LSD}_{5 \%}$ & 24 & 124 & 21 & 233 & 32 & 244 \\
\hline \multicolumn{7}{|c|}{2008} \\
\hline Not irrigated & 202 & 13809 & 210 & 14056 & 249 & 13622 \\
\hline Irrigated & 216 & 12893 & 202 & 14158 & 212 & 14089 \\
\hline Yield increment & - & -916 & - & 102 & - & 467 \\
\hline $\mathrm{LSD}_{5 \%}$ & 24 & 418 & 18 & 502 & 23 & 468 \\
\hline \multicolumn{7}{|c|}{2009} \\
\hline Not irrigated & 324 & 8774 & 318 & 12329 & 336 & 10160 \\
\hline Irrigated & 341 & 10973 & 242 & 13968 & 339 & 12858 \\
\hline Yield increment & - & 2199 & - & 1639 & - & 2698 \\
\hline $\mathrm{LSD}_{5 \%}$ & 17 & 322 & 24 & 533 & 13 & 492 \\
\hline
\end{tabular}

\section{CONCLUSIONS}

In the tendencies of the three studied crop years the good water management properties, just as its excellent water storage and infiltration capacity of the chernozem soil is proven. Through these properties the soil is able to moderate climatic effects and compensate to some extent or rather balance water management circumstances that are unfavourable for the plant.

Due to the even more extreme weather conditions drastic effects can be observed in the upper $0-60 \mathrm{~cm}$ soil layer parallel to plant growth. Soil moisture stock showed a decreasing tendency with smaller deviances from the beginning of the vegetation period in all three studied crop years. In the phase of flowering and grain production of maize it reached a minimal value and in September depending on the amount and distribution of the fallen precipitation it increased again. The 121$200 \mathrm{~cm}$ soil layer was the one from the studied three layers that was the less affected by the effects of plant water uptake, precipitation or irrigation respectively. Moisture content of this layer is mainly affected by the extent how winter precipitation fills it up. In the studied three crop years - depending on the extent of this filling up moisture content values between 20 and $24 \mathrm{~V} / \mathrm{V} \%$ were measured in the beginning of the vegetation. Then with time they showed a decreasing tendency in the vegetation and the drastic decrease was observed in the months July and August too.
Regarding the development of soil moisture content in the three studied crop years in general it can be stated that soil moisture content varied during the whole vegetation period in the upper $0-60 \mathrm{~cm}$ soil layer in the greatest extent. In this layer irrigation water has the greatest effect and precipitation increases soil moisture content volume percent values the most, nevertheless, water uptake of the large root biomass of maize is the most intensive here. The development of the soil moisture content of the $61-120 \mathrm{~cm}$ layer is more balanced; the decrement of it is not so expressed as in the upper layer. The layer $121-200 \mathrm{~cm}$ plays indirect role in water transport processes and water supply of maize plants via capillary water transport, so the change of soil moisture content is the most balanced here. Significant decrease can be observed in August, the grain filling phonological phase of the crop, when the layer above it dries out and water is transported and supplied from this layer to it.

Development of water management of the plant production space has a significant effect on yield amounts too. Among the three studied crop rotation systems it is the triculture that is the most favourable from the aspect of both the yield amount of the crops in the cropping system and the favourable soil properties. In contrast the effectivity of the monoculture cropping system depends on the water supply circumstances the most. In case of the not irrigated treatments the yields showed the highest values in the biculture system that can be explained by the favourable water management of the bicultural crop rotation system. 


\section{REFERENCES}

Antal J.-Jolánkai M. (2005): Növénytermesztéstan 1. A növénytermesztéstan alapjai. Gabonafélék. Mezőgazda Kiadó. Budapest. 315-316.

Bharati, V.-Nandan, R.-Kumar, V.-Kumar, S. B. (2007): Effect of irrigation on yield, water-use efficiency and water requirement of winter maize (Zea mays L.)-based intercropping systems. Enviroment and Ecology. 25. 4: 888-892.

Blaskó L.-Zsigrai Gy. (2000): A mütrágyázás hatása a kukorica termésére és néhány talajjellemzőre réti csernozjom talajon. Gyakorlati Agrofórum. 11. 3: 48-50.

Buzás I. (1993): Talaj- és agrokémiai vizsgálati módszerkönyv 1. Inda 4231 Kiadó. Budapest. 357.

Dégen I. (1967): A vízgazdálkodás népgazdasági jelentősége. [In Kádár B. (1970): Öntöző gazdaságok vetésszerkezetének kialakítása.] Akadémiai Kiadó. Budapest. 8.

Huzsvai, L.-Nagy, J. (2005): Effect of weather on maize yields and the efficiency of fertilization. Acta Agronomica Hungarica. 53. 1: 31-39.

Izsáki Z. (2006): A N- és P-ellátottság hatása a kukoricaszem (Zea mays L.) fehérjetartalmára éa aminosav összetételére. Növénytermelés. 55. 3-4: 213-230.
Kismányoky T.-Debreczeni K. (2002): A búza és kukorica mütrágyázásának tapasztalatai az országos mütrágyázási tartamkísérletekben. [In: Pepó P.-Jolánkai M. (szerk.) Integrációs feladatok a hazai növénytermesztésben.] II. Növénytermesztési Tudományos Nap. Magyar Tudományos Akadémia Növénytermesztési Bizottság. Budapest. 133-137.

Kismányoky T. (2005): A globális klímaváltozás hatásai és válaszai Közép- és Dél-Dunántúl szántóföldi növénytermelésében. „AGRO-21” Füzetek. Klímaváltozás - hatások - válaszok. 41: 81-94.

Kruzsilin A. Sz. (1964): Az öntözés rendje különböző éghajlati zónákban. [In: Mihályfalvy I.-Németh S. (1967): A fontosabb szántóföldi növények vízigénye, öntözési normái és vízhasznosítása.] Károlyi Mihály Országos Mezőgazdasági Könyvtár és Dokumentációs Központ. Budapest. 15.

Kumar, A. (2008): Growth, yield and water use efficiency of different maize (Zea mays L.)-based cropping systems under varying planting methods and irrigation levels. Indian Journal of Agricultural Sciences. Indian Council of Agricultural Research. New Delhi. India. 78. 3: 244-247.

Nagy J.-Kovács J. (2005): Az öntözéses mezőgazdaság klímabefolyásoló hatása. „AGRO-21” Füzetek. Klímaváltozás - hatások - válaszok. 43: 21.

Nagy J. (2007): Kukoricatermesztés. Akadémiai Kiadó. Budapest. 69. Surányi J. (1957): A kukorica és termesztése. Akadémiai Kiadó. Budapest. 279 . 
